\title{
EPINEPHRINE AND DEXAMETHASONE AS ADJUVANTS IN UPPER EXTREMITY PERIPHERAL NERVE BLOCKS IN PEDIATRIC PATIENTS
}

\author{
Ljubica Mikjunovikj-Derebanova ${ }^{1}$, Andrijan Kartalov ${ }^{1,2}$, Biljana Kuzmanovska ${ }^{1,2}$, \\ Ljupcho Donev $^{1}$, Albert Lleshi ${ }^{1}$, Marija Toleska ${ }^{1}$, Aleksandar Dimitrovski ${ }^{1}$, Vasko Demjanski ${ }^{1}$ \\ ${ }^{1}$ University Clinic for Anesthesiology, Reanimation and Intensive Care Medicine, University "St Cyril and Methodius", Skopje, \\ R.N. Macedonia \\ ${ }^{2}$ Medical Faculty, University “Ss. Cyril and Methodius”, Skopje, R.N.Macedonia
}

Corresponding author: Ljubica Mikjunovikj-Derebanova, MD, University Clinic for Anesthesiology, Reanimation and Intensive Care Medicine, University "St Cyril and Methodius", Skopje, R. North Macedonia, Mother Theresa St 17, 1000 Skopje, R.N. Macedonia, e-mail: bubemicun@yahoo.com

ABSTRACT

Introduction: Regional anesthesia in children in recent years has been accepted worldwide. The increased interest in it is partly due to the use of ultrasonography which provides confidence and accuracy to the anesthesiologic team. Adjuvants are used to extend the duration of the sensory and motor blocking, limiting the cumulative dose of local anesthetics. The use of adjuvants in peripheral nerve blocks in the pediatric population is still under research.

Aim: To observe the effect of epinephrine and dexamethasone as adjuvants to local anesthetics in peripheral upper extremity nerve blocks in pediatric patients.

Materials and methods: The study included 63 patients, aged group 4-14 years, admitted to the University Clinic of Pediatric Surgery for surgical treatment of upper limb fractures in the period of January 2020 until March 2021. Patients were randomized into three groups, and all patients in the groups received analgo-sedation prior to peripheral nerve block. Patients in group 1 (21 patients) received supraclavicular, or interscalene block with $2 \mathrm{ml}$ lidocaine $2 \%$ and bupivacaine $0.25 \%(\max 2 \mathrm{mg} / \mathrm{kg})$ with a total volume of $0.5 \mathrm{ml} / \mathrm{kg}$. In group 2, the patients (21) received $25 \mu \mathrm{g}$ of epinephrine in $2 \mathrm{ml}$ of $2 \%$ solution of lidocaine and $0.25 \%$ bupivacaine $(\max 2 \mathrm{mg} / \mathrm{kg}$ ) with a total volume of $0.5 \mathrm{ml} / \mathrm{kg}$, and in group 3, the patients (21) received $2 \%$ lidocaine $2 \mathrm{ml}$ and $0.25 \%$ bupivacaine ( $\max 2 \mathrm{mg} / \mathrm{kg}$ ) in combination with $2 \mathrm{mg}$ dexamethasone with a total volume of $0.5 \mathrm{ml} / \mathrm{kg}$.

Results: Results showed that in patients in group 1, the average duration of the sensory block was 7 hours, while the duration of the motor block was 5 hours and 30 minutes. In group 2 (epinephrine), the durations of both sensory and motor block were prolonged for about 30 minutes on average compared to the first group. In group 3 (dexamethasone) the duration of the sensory and motor block was significantly longer compared with the first two groups $(\mathrm{p}<0.0001)$.

Conclusion: Epinephrine and dexamethasone prolong the duration of action of local anesthetics in peripheral nerve blocks of the upper extremity in pediatric patients and thus reduce the need for analgesics in the postoperative period.

Keywords:epinephrine, dexamethasone, adjuvants, plexus brachialis blocks, pediatric patients 


\section{INTRODUCTION}

Peripheral nerve blocks in pediatric surgery has become increasingly used and accepted in recent years. [1] Peripheral nerve blocks can be very challenging in pediatric patients because their anatomical structures are poorly defined and vary with age. Neuroaxial and peripheral nerve blocks are administered under general anesthesia or in deep analgesia in pediatric patients, therefore, regional anesthesia in children requires special attention. Peripheral nerve blocks of the upper extremity involve the plexus brachialis block at several levels: interscalene, supraclavicular, infraclavicular, and axillary approach, depending on the region that needs to be operated on, i.e. shoulder, upper arm, forearm, or wrist.

Ultrasonography allows direct visualization of the correct position of the needle and the spread of the local anesthetic, thus reducing the risk of complications, the total volume of local anesthetic applied, and thereby increasing the success of the peripheral nerve block, thus providing greater confidence in anesthesiologists. [2,3] When difficulties arise when defining nerve structures using ultrasound due to anatomical variations in altered echogenicity, the neurostimulator helps to define these structures more accurately. [4]

The purpose of using adjuvants is to increase the duration of the block without increasing the total volume applied and with minimal side effects. [5] It is expected that adding another drug to local anesthetics would reduce the need for high doses of anesthetics, thus their side effects would be avoided, such as local anesthetics systemic toxicity (LAST). This addition of a drug together with local anesthetics is called "multimodal perineural analgesia". $[6,7]$

\section{AIM OF THE STUDY}

The primary aim of the study was to determine whether epinephrine and dexamethasone administered as adjuvants to local anesthetics in peripheral nerve blocks of the upper extremity in pediatric patients would delay and reduce the need for postoperative analgesics 48 hours postoperatively. The effects of epinephrine and dexamethasone on motor block duration are secondary objectives of the study as well as the comparison of the effects of these two drugs as adjuvants.

\section{METHODS}

The research is a randomized retrospective-prospective single-blind study, conducted from January 2020 to March 2021. The study included 63 patients aged 4-14 years, ASA classification group I or II admitted to the University Clinic of Pediatric Surgery for surgical treatment of a fracture of the upper limb (shoulder, upper arm, forearm, or wrist). Patients whose parents or guardians refused to sign informed consent, patients under 4 years of age and older then 15 years, patients in ASA classification group $\geq$ III, patients with diabetes mellitus, coagulopathy or local infection of site where peripheral nerve block should be applied, and patients receiving systemic corticosteroids were excluded from the study. All patients included in the study received premedication (midazolam syrup $0.4 \mathrm{mg} / \mathrm{kg}$ p.o.) 15 minutes preoperatively. Patients were randomized into three groups. In the first group (control group CG) a supraclavicular or interscalene block was performed by administering $2 \mathrm{ml}$ lidocaine $2 \%$ and bupivacaine $0.25 \%(\max 2 \mathrm{mg} / \mathrm{kg})$ with a total volume of $0.5 \mathrm{ml} / \mathrm{kg}$. In the second group of patients (epinephrine group EG), $25 \mu \mathrm{g}$ epinephrine was administered in $2 \mathrm{ml}$ of lidocaine $2 \%$ solution and $0.25 \%$ bupivacaine ( $\max 2 \mathrm{mg} / \mathrm{kg}$ ) with a total volume of $0.5 \mathrm{ml} / \mathrm{kg}$, and in the third group (dexamethasone group DG) $2 \%$ lidocaine 2 $\mathrm{ml}$ and $0.25 \%$ bupivacaine ( $\max 2 \mathrm{mg} / \mathrm{kg}$ ) in combination with $2 \mathrm{mg}$ dexamethasone with a total volume of $0.5 \mathrm{ml} / \mathrm{kg}$. In order to provide deep analgesia and safe conditions for performing peripheral nerve blocks in pediatric patients, analogo-sedation was performed with: midazolam $0.1 \mathrm{mg} / \mathrm{kg}$ i.v., fentanyl $1 \mu \mathrm{g} / \mathrm{kg}$ i.v. and propofol $5-10 \mathrm{mg} /$ $\mathrm{kg} / \mathrm{h}$. $[8,9,10]$ Vital signs (heart rate, blood pressure, saturation, and capnography) were recorded prior performing the peripheral nerve block, during surgery, and $30 \mathrm{~min}$. postoperatively. Capillary blood glucose was measured in all patients prior to blockade and two hours after peripheral nerve block administration.

The brachial plexus block was performed by placing the patient in a supine position with the arm that is to be anesthetized placed next to the body and the head, turned contralateral to the affected side. The Stimuplex HNS 11 neurostimulator and the Siemens ACUSON P500 ultrasound device with a linear probe of 8-12 $\mathrm{MHz}$ were used to perform the peripheral nerve 
block. The plexus brachialis was visualized by placing the ultrasound linear probe parallel to the collarbone in the supraclavicular fossa, as a cluster of 5-6 hypoechoic circles lateral to a. subclavia (supraclavicular block) or as 3-4 hypoechoic circles arranged one below the other between the anterior and middle scalene muscle (interscalene block). The operation started 15-20 minutes after performing the block. Surgical interventions where we used these peripheral nerve blocks were open repositioning with fixation or closed bloodless repositioning with percutaneous fixation.

The duration of the sensory and motor block was monitored postoperatively. The intensity of pain was assessed according to the visual analog scale (VAS), if the patient knew how to count to 10 and to grade the pain from 0 to 10 , where 0 is the absence of pain and 10 is the strongest possible pain. Another option was with the scale of face, legs, activity, cry and consolability (FLACC) if the patient does not know how to count to 10. [11-13] The duration of the sensory block was defined by the time of application of the peripheral nerve block to the administration of the first postoperative non-opioid analgesic. The first non-opioid analgesic (acetaminophen $15 \mathrm{mg}$ / $\mathrm{kg}$ i.v.) was administered when pain intensity was assessed above 5 on the VAS or FLACC scale.

The motor block was monitored through the motor block scale (MBS) as follows:

1. Unable to move fingers;
2. Able to move the fingers, but weaker than the other hand;

\section{Same motor strength in both hands}

The duration of the motor block was defined by the time from application of the peripheral nerve block to the return of motor strength, a value of MBS 3 .

The pain intensity, motor strength and the need for non-opiate analgesics were monitored every two hours for 48 hours postoperatively.

\section{RESULTS}

Patients in the control group, the epinephrine group, and the dexamethasone group were averaged $8.4 \pm 2.6,7.3 \pm 2.6$, and $8.6 \pm 2.7$ years old, respectively, and with averaged weight $36.67 \pm 18.9,29.86 \pm 13.3$, and $34.33 \pm 12.8 \mathrm{~kg}$.

The majority of the patients in the control group were male - $12(57.1 \%)$, whereas the majority of the patients in the epinephrine group were more often female - $11(52.4 \%)$ and the dexamethasone group was predominantly comprised of male patients - $17(80.95 \%)$.

In the control group and the epinephrine group, percutaneous bloodless reposition was performed more often - $12(57.1 \%)$ and 14 (66.75), respectively, while in the patients from the dexamethasone group, open operative technique was used more often - $11(52.4 \%)$.

Table 1. Descriptive statistics of the three groups by age, weight, gender, type of operation and block

\begin{tabular}{|c|c|c|c|c|}
\hline \multirow[b]{2}{*}{ Variable } & \multicolumn{3}{|c|}{ Groups } & \multirow[b]{2}{*}{ p-level } \\
\hline & Control group & $\begin{array}{l}\text { Epinephrine } \\
\text { groun }\end{array}$ & $\begin{array}{c}\text { Dexamethasone } \\
\text { groun }\end{array}$ & \\
\hline \multicolumn{5}{|l|}{ Age / years } \\
\hline mean $\pm \mathrm{SD}$ & $8.4 \pm 2.6$ & $7.3 \pm 2.6$ & $8.6 \pm 2.7$ & $\mathrm{~F}=1.47$ \\
\hline $\min -\max$ & $4-13$ & $4-13$ & $5-13$ & $\mathrm{p}=0.24 \mathrm{~ns}$ \\
\hline \multicolumn{5}{|l|}{ Weight / kg } \\
\hline mean $\pm \mathrm{SD}$ & $36.67 \pm 18.9$ & $29.86 \pm 13.3$ & $34.33 \pm 12.8$ & $\mathrm{~F}=1.08$ \\
\hline $\min -\max$ & $17-75$ & $13-61$ & $18-65$ & $\mathrm{p}=0.35 \mathrm{~ns}$ \\
\hline \multicolumn{5}{|l|}{ Gender } \\
\hline female & $9(42.86)$ & $11(52.38)$ & $4(19.05)$ & $\mathrm{X}^{2}=5.25$ \\
\hline male $\quad \mathrm{n}(\%)$ & $12(57.14)$ & $10(47.62)$ & $17(80.95)$ & $\mathrm{p}=0.07 \mathrm{~ns}$ \\
\hline \multicolumn{5}{|l|}{ Type of operation } \\
\hline closed $\quad n(\%)$ & $12(57.14)$ & $14(66.67)$ & $10(47.62)$ & $\mathrm{X}^{2}=1.56$ \\
\hline open $\quad n(\%)$ & $9(42.86)$ & $7(33.33)$ & $11(52.38)$ & $\mathrm{p}=0.46 \mathrm{~ns}$ \\
\hline \multicolumn{5}{|l|}{ Type of block } \\
\hline Supraclavicular & $13(61.9)$ & $20(95.24)$ & $19(90.48)$ & Fisher exact \\
\hline Interscalene & $8(38.1)$ & $1(4.76)$ & $2(9.52)$ & $\mathrm{p}=0.017^{*}$ \\
\hline
\end{tabular}

F (Analysis of Variance); $\mathrm{X}^{2}$ (Pearson Chi-square); ${ }^{*} \mathrm{p}<0.05 \mathrm{sig}$ 
A supraclavicular block was performed on $13(61.9 \%)$ patients in the control group, $20(95.2 \%)$ in the epinephrine group, and 19 $(90.5 \%)$ in the dexamethasone group, while an interscalenic block was performed on $8(38.1 \%)$ patients in the control group, 1 ( 4.85) from the epinephrine group, and $2(9.5 \%)$ patients from the dexamethasone group.

The results of the statistical analysis showed that the patients from the three groups were homogeneous, similar in terms of age $(\mathrm{p}=$ $0.24)$, body weight $(\mathrm{p}=0.35)$, gender structure $(p=0.07)$ and type of surgery $(p=0.46)$. Patients in the three groups significantly differed in the applied block type $(\mathrm{p}=0.017)($ Table 1$)$.

The duration of sensory block differed significantly between patients in the three groups ( $p$ $<0.0001$ ). Post-hoc analysis for intergroup comparisons showed that this total significance was due to the significantly longer duration of sensory block in the dexamethasone group of patients compared to the control group and the epinephrine group $(\mathrm{p}=$ 0.00012 ). The mean duration of the sensory block was $7.24 \pm 1.6,7.79 \pm 1.7$ and $13.62 \pm 3.02$ hours, respectively in the control, epinephrine, and dexamethasone groups (Table 2, Figure 1).

A statistically significant difference was confirmed between the patients in the control group and the two examined groups, in terms of the duration of the motor block $(\mathrm{p}<0.0001)$. Intergroup comparisons as statistically significant confirmed the difference between the control and dexamethasone groups $(5.40 \pm 1.5$ vs $9.38 \pm 1.7)$, and between the epinephrine and dexamethasone groups $(5.93 \pm 1.7$ vs $9.38 \pm 1.7), \mathrm{p}=0.00011$ (Table 3, Figure 2).

The frequency of analgesic administration within 48 hours postoperatively is shown in Table 4. In most patients in the control group, analgesic was administered four times - $16(76.2 \%)$, from the epinephrine group, the analgesic was received in $10(47.6 \%)$ patients three times and $11(52.4 \%)$ patients received it four times. Most patients from the dexamethasone group received analgesic twice in this period - $11(52.4 \%)$.

The difference between the patients in the three groups in terms of how many times the analgesic was administered postoperative-

Table 2. Descriptive statistic for duration of sensory block in the three groups

\begin{tabular}{|c|c|c|c|}
\hline \multirow{2}{*}{ Groups } & \multicolumn{2}{|c|}{$\begin{array}{l}\text { Descriptive statistics - } \\
\text { duration of sensory block / hours }\end{array}$} & \multirow{2}{*}{ p-level } \\
\hline & mean $\pm \mathrm{SD}$ & $\min -\max$ & \\
\hline Control group & $7.24 \pm 1.6$ & $4-10.5$ & \multirow{3}{*}{$\begin{array}{l}\mathrm{F}=53.8 \mathrm{p}=0.00000 * * * \\
\text { Dexamethasone vs CG and } \\
\text { epinephrine } \mathrm{p}=0.00012 * * *\end{array}$} \\
\hline Epinephrine group & $7.79 \pm 1.7$ & $4-12$ & \\
\hline Dexamethasone group & $13.62 \pm 3.02$ & $9-19$ & \\
\hline
\end{tabular}

$\mathrm{F}$ (Analysis of Variance), post-hoc Tukey honest; ***p<0.0001 sig

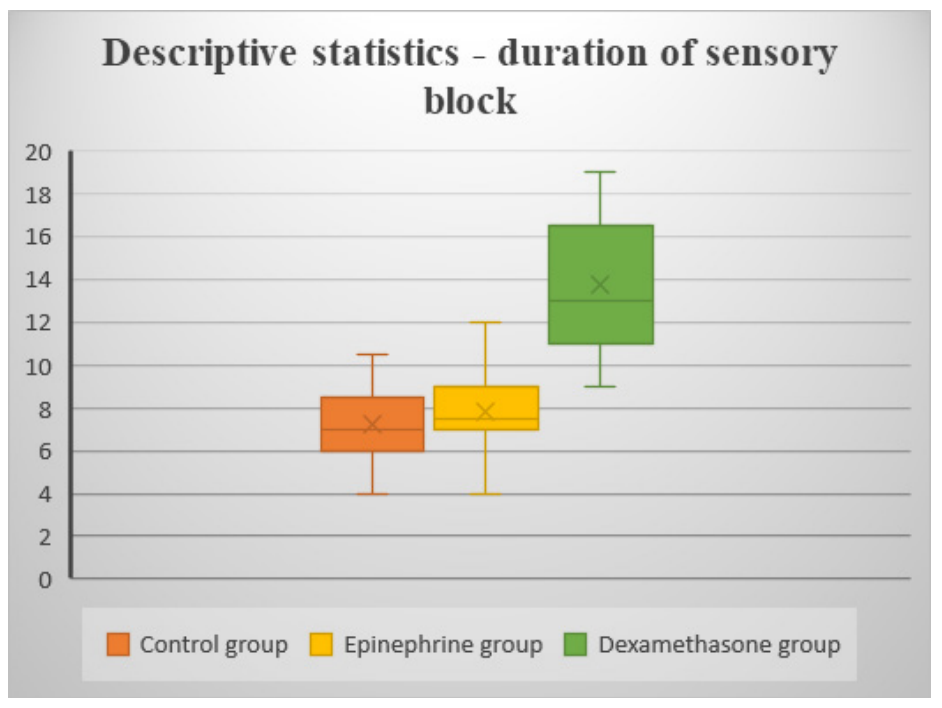

Figure 1. Descriptive statistic for duration of sensory block in the three groups 
ly was statistically confirmed to be significant $(\mathrm{p}<0.0001)$. Post-hoc analysis for intergroup comparisons showed that this total significance is due to the significantly more frequent analgesic administration in the control group versus the dexamethasone group, with a significance of $p$ $=0.000001$, and significantly more frequent analgesic administration in the epinephrine group versus the dexamethasone group, with a significance of $p=0.0006$.
According to the results shown in Table 5, the duration of the sensory block did not depend significantly on the type of operation or on the type of applied block. In the whole group of patients, as well as in each group separately, the duration of the sensory block did not differ significantly, it was similar in patients with closed and open type of surgery ( $p>0.05)$, as well as in patients with supraclavicular and interscalene block $(\mathrm{p}>0.05)$.

Table 3. Descriptive statistic for duration of motor block in the three groups

\begin{tabular}{|c|c|c|c|}
\hline \multirow{2}{*}{ Groups } & \multicolumn{2}{|c|}{$\begin{array}{l}\text { Descriptive statistics - } \\
\text { duration of motor block / hours }\end{array}$} & \multirow{2}{*}{ p-level } \\
\hline & mean \pm SD & $\min -\max$ & \\
\hline $\mathrm{CG}$ & $5.40 \pm 1.5$ & $3-9$ & \multirow{3}{*}{$\begin{aligned} \mathrm{F}= & 34.8 \mathrm{p}=0.00000^{* * *} \\
& \text { Dexamethasone vs } \mathrm{CG} \text { and } \\
& \text { epinephrine } \mathrm{p}=0.00011^{* * *}\end{aligned}$} \\
\hline Epinephrine group & $5.93 \pm 1.7$ & $3-11$ & \\
\hline Dexamethasone group & $9.38 \pm 1.7$ & $7-14$ & \\
\hline
\end{tabular}

$\mathrm{F}$ (Analysis of Variance), post-hoc Tukey honest; ***p $<0.0001$ sig

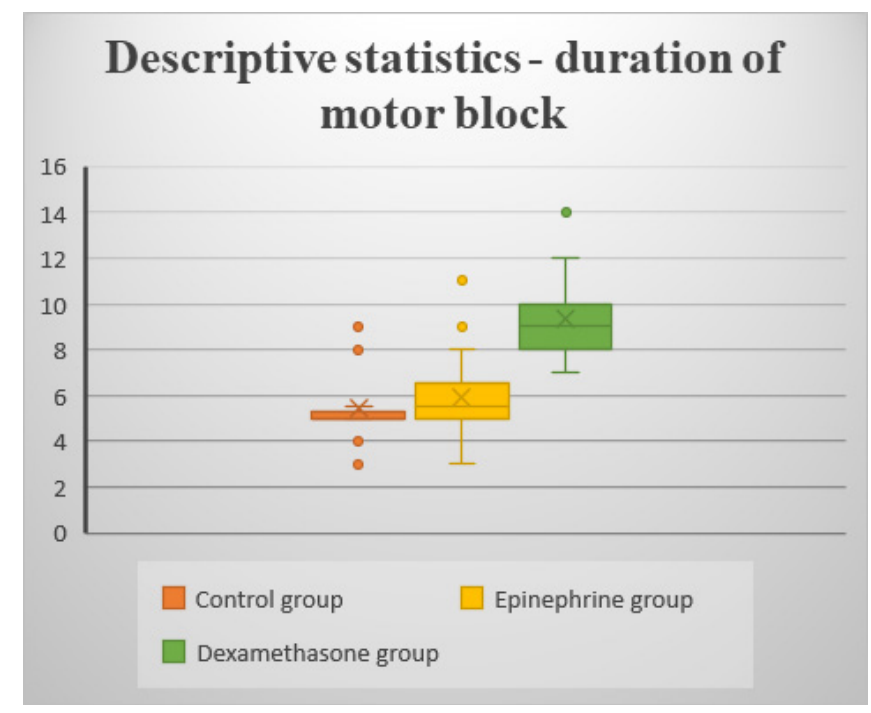

Figure 2. Descriptive statistic for duration of motor

block in the three groups

Table 4. Frequency of analgesic administration within 48 hours postoperatively

\begin{tabular}{|c|c|c|c|c|c|}
\hline \multirow{2}{*}{$\begin{array}{l}\text { Analgesic } \\
48 \text { hours } \\
\text { postoperatively }\end{array}$} & \multicolumn{4}{|c|}{ Groups } & \multirow[b]{2}{*}{ p-level } \\
\hline & $\mathbf{n}$ & $\begin{array}{l}\text { Control } \\
\text { group } \\
\mathrm{n}(\%) \\
\end{array}$ & $\begin{array}{l}\text { Epinephrine } \\
\text { group } \\
n(\%) \\
\end{array}$ & $\begin{array}{c}\text { Dexamethasone } \\
\text { group } \\
n(\%) \\
\end{array}$ & \\
\hline 2 & 11 & 0 & 0 & $11(52.38)$ & \multirow{5}{*}{$\begin{array}{l}\mathrm{H}=32.7 \mathrm{p}=0.00000 * * * \\
\mathrm{CG} \text { vs dexamethasone } \\
\mathrm{p}=0.000001 * * * \\
\text { epinephrine vs dexamethasone } \\
\mathrm{p}=0.0006 * * *\end{array}$} \\
\hline 3 & 23 & $4(19.05)$ & $10(47.62)$ & $9(42.86)$ & \\
\hline 4 & 28 & $16(76.19)$ & $11(52.38)$ & $1(4.76)$ & \\
\hline 5 & 1 & $1(4.76)$ & 0 & 0 & \\
\hline median (IQR) & & $4(4-4)$ & $4(3-4)$ & $2(2-3)$ & \\
\hline
\end{tabular}

$\mathrm{H}$ (Kruskal-Wallis test), post-hoc Mann-Whitney test; ***p<0.0001sig 
Table 5. Statistical analysis between duration of sensory block and the type of operation and block

\begin{tabular}{|c|c|c|c|c|c|}
\hline \multirow{2}{*}{ Groups } & \multirow{2}{*}{ Variable } & \multicolumn{3}{|c|}{$\begin{array}{l}\text { Descriptive statistics - } \\
\text { duration of sensory block/hours }\end{array}$} & \multirow{2}{*}{ p-level } \\
\hline & & $\mathbf{n}$ & mean \pm SD & $\min -\max$ & \\
\hline \multirow{6}{*}{$\underset{N=63}{\text { All }}$} & \multicolumn{5}{|c|}{ Type of operation } \\
\hline & Closed & 36 & $9.46 \pm 3.7$ & $4-19$ & $\mathrm{t}=0.22$ \\
\hline & Open & 27 & $9.67 \pm 3.6$ & $4-18$ & $\mathrm{p}=0.82 \mathrm{~ns}$ \\
\hline & \multicolumn{5}{|c|}{ Type of block } \\
\hline & Supraclavicular & 52 & $9.64 \pm 3.5$ & $4-19$ & $\mathrm{t}=0.46$ \\
\hline & Interscalene & 11 & $9.09 \pm 4.2$ & $4-18$ & $\mathrm{p}=0.65 \mathrm{~ns}$ \\
\hline \multirow{6}{*}{$\begin{array}{c}\text { Control group } \\
\mathbf{N}=\mathbf{2 1}\end{array}$} & \multicolumn{5}{|c|}{ Type of operation } \\
\hline & Closed & 12 & $7.33 \pm 1.3$ & $6-10.5$ & $\mathrm{t}=0.31$ \\
\hline & Open & 9 & $7.11 \pm 2.01$ & $4-10$ & $\mathrm{p}=0.76 \mathrm{~ns}$ \\
\hline & \multicolumn{5}{|c|}{ Type of block } \\
\hline & Supraclavicular & 13 & $7.46 \pm 1.7$ & $5-10.5$ & $\mathrm{t}=0.81$ \\
\hline & Interscalene & 8 & $6.87 \pm 1.4$ & $4-9$ & $\mathrm{p}=0.43 \mathrm{~ns}$ \\
\hline \multirow{6}{*}{$\begin{array}{l}\text { Epinephrine group } \\
\qquad \mathrm{N}=21\end{array}$} & \multicolumn{5}{|c|}{ Type of operation } \\
\hline & Closed & 14 & $7.96 \pm 1.96$ & $4-12$ & $\mathrm{t}=0.66$ \\
\hline & Open & 7 & $7.43 \pm 1.1$ & $6-9$ & $\mathrm{p}=0.51 \mathrm{~ns}$ \\
\hline & \multicolumn{5}{|c|}{ Type of block } \\
\hline & Supraclavicular & 20 & $7.57 \pm 1.5$ & $4-11$ & \\
\hline & Interscalene & 1 & 12.0 & & \\
\hline \multirow{6}{*}{$\begin{array}{c}\text { Dexamethasone } \\
\text { group } \\
\mathbf{N}=\mathbf{2 1}\end{array}$} & \multicolumn{5}{|c|}{ Type of operation } \\
\hline & Closed & 10 & $14.10 \pm 3.5$ & $9-19$ & $\mathrm{t}=0.68$ \\
\hline & Open & 11 & $13.18 \pm 2.6$ & $9-18$ & $\mathrm{p}=0.5 \mathrm{~ns}$ \\
\hline & \multicolumn{5}{|c|}{ Type of block } \\
\hline & Supraclavicular & 19 & $13.32 \pm 2.98$ & $9-19$ & \\
\hline & Interscalene & 2 & $16.50 \pm 2.1$ & $15-18$ & \\
\hline
\end{tabular}

$\mathrm{t}$ (Student t-test)

\section{DISCUSSION}

Peripheral nerve blocks among the pediatric population has become increasingly popular in recent years. In children, the intensity of pain is often underestimated, and there is also fear of the risk of complications when using opioids, therefore pediatric patients often have inadequate treatment of pain, especially after painful procedures. The use of ultrasound helps to identify nerves during regional anesthesia and thus has reduced the risk of complications from interscalene and supraclavicular block (intrathecal and intravascular injection of a local anesthetic, hematoma, pneumothorax). In addition, a neurostimulator is used with ultrasound for accurate localization and to further identify nerve structures.

One life-threatening complication that can happen from using high doses of local anesthetics is systemic toxicity (LAST). Due to weaker protein binding and decreased internal clearance of the local anesthetic in infants and young children, neurotoxicity and cardiotoxicity associated with high concentrations of local anesthetics in the blood are more likely to occur in this age than in adults. [14] Neurotoxicity (seizures) is best treated with benzodiazepines or propofol while the most successful treatment for LAST-associated cardiotoxicity is the administration of a lipid emulsion, which is now considered as first-line therapy. New case reports have shown that the rapid intravenous bolus of lipid emulsion reverses the toxic effects of local anesthetics in pediatric patients. [15] Safe doses for lipid resuscitation must be defined for infants and children because complications of lipid overdose have been reported in infants receiving parenteral nutrition. [16] The recommended dose of $20 \%$ Interlipid for pediatric patients is $1-3 \mathrm{ml} / \mathrm{kg}$. Although the 
exact mechanism of action of the lipid emulsion has not been defined, the current hypothesis explaining its effect in in vitro studies suggests that it binds to a circulating lipophilic toxin and thus reduces the amount of free toxin available to bind to the myocardium. [17] Resuscitation with lipids may be a life-saving treatment in pediatric patients when LAST is diagnosed. $[10,18$, 19] Dose-dependent side effects can be caused by local anesthetics, such as: hypertension, cardiac arrhythmias, epileptic seizures, respiratory depression, and allergic reactions. Adjuvants are added to the local anesthetics in order to reduce the dose of the local anesthetic while achieving and prolonging the desired sensor-motor block.

Epinephrine is one of the oldest adjuvants to local anesthetics with a recommended dose of $0.5-1.0 \mu \mathrm{g} / \mathrm{kg}$ at a concentration of $5-10 \mu \mathrm{g} / \mathrm{ml}$. Applied perineurally, it is considered to have no direct effect on nerve fiber conduction, but reduces the absorption of local anesthetic into blood vessels and thus prolongs the duration of contact of the local anesthetic with nerve fibers. [20] Due to this effect, it must be used with precaution, or better, avoided in patients with pre-existing circulatory problems (diabetes mellitus, hypertension, smokers). [21, 24, 25] In peripheral nerve blocks, epinephrine shows some analgesic effects in combination with short-acting and intermediate-acting local anesthetics such as lidocaine, but similar effects have not been observed in combination with long-acting local anesthetics such as bupivacaine and ropivacaine.[22, 23] An epinephrine solution of $25 \mu \mathrm{g} / \mathrm{ml}$ may be an effective marker for intravascular injection of a local anesthetic. It has been suggested that this dose may also transiently increase blood flow to the peripheral nerve itself, probably due to its $\beta$-adrenergic effects. [26] Also, epinephrine reduces the risk of local anesthetic systemic toxicity (LAST) by limiting the distribution of local anesthetic in the systemic circulation due to its vasoconstrictive effect. [27]

This study has shown that the addition of epinephrine as an adjuvant to local anesthetics extended the duration of sensory and motor block by an average of 30 minutes. In the epinephrine group the duration of the sensory block was 4 to 12 hours $(7.79 \pm 1.7)$, and the duration of the motor block was 3 to 11 hours $(5.93 \pm 1.7)$ which is 30 minutes longer than in the control group or the group without adjuvant ( $7.24 \pm 1.6$, $5.40 \pm 1.5$, respectively; $p<0.0001)$.
Compared to the group in which patients received dexamethasone as an adjuvant, the duration of the sensory block was 9 to 19 hours $(13.62 \pm 3.02)$ which is on average 390 minutes longer than the group without adjuvant, and 360 minutes longer than the group with epinephrine as an adjuvant. The duration of motor block in patients with dexamethasone was extended by an average of 240 min compared with patients who did not receive adjuvant $(\mathrm{p}=0.00011)$.

The need for postoperative analgesia was twice reduced in patients receiving dexamethasone compared with patients who did not receive the adjuvant $(\mathrm{p}<0.0001)$. There were no adverse systemic changes (changes in heart rate, blood pressure, glycaemia, infection, or slow healing of the operative wound) or any complications from performing a peripheral nerve block reported among any of the patients in all three groups.

Dexamethasone is a potent long-acting glucocorticoid with minimal mineralocorticoid activity. When applied perineurally, its mechanism of action reduces excitability and transmission of nociceptive demyelinating C fibers. [28] Dexamethasone must be administered as a non-derivative preparation, such as benzyl alcohol or propylene, which may cause neurolytic effects. [29] Unlike bupivacaine and lidocaine, ropivacaine exposed to the alkalinity of dexamethasone can crystallize, proving their incompatibility in vitro. [30] Delayed wound healing or surgical wound infection has not been reported with perineural administration of dexamethasone. [31] Several studies have shown that perineural administration of dexamethasone $(1,2$, and $4 \mathrm{mg}$ ) prolongs analgesia and motor blockade of bupivacaine applied in supraclavicular block for upper limb surgery. [32, 33] There is still debate and numerous studies as to whether there it is advantageous if dexamethasone is administered perineurally or intravenously. [34]

\section{CONCLUSION}

Epinephrine and dexamethasone are safe drugs that can be used as adjuvants to local anesthetics. Both adjuvants prolong the duration of action of local anesthetics in peripheral nerve blocks of the upper extremity among pediatric patients. They extend the time required to administer the first analgesic postoperatively, and 
thus reduce the need for analgesics. It can be said that dexamethasone is an adjuvant with the most optimal clinical effect and the safest profile that can be used in pediatric patients.

\section{REFERENCES}

1. Eccoffey C, Lacroix F, Gainfre E, Orliaquet G, Courreges P, Association des Anesthesistes Reanimatueurs Pediatriques d'Expression Francaise (ADARPEF). Epidemiology and Morbidity of regional anesthesia in children: a follow up one year prospective survey of the French-Language Society of Paediatric Anesthesiologists (ADARPEF). Pediatr Anesth 2010; 20: 10611069.

2. Capdevila X, Biboulet PH, Morau D, Mannion $\mathrm{S}$, Choquet O. How and why to use ultrasound for regional blockade Acta Anaesth. Belg., 2008; 59: 147-154.

3. Mikjunovikj Derebanova Lj., Kartalov A., Donev Lj., Leshi A., Tolevska M., Demjanski V.: Epinephrine and dexamethasone as adjuvans in supraclavicular block in pediatric patients: a case series, Macedonian Journal of Anesthesia Vol 5, No 2, 2021, 52-58, UDC: 616.833.34-089.5053.2 .

4. Orebaugh SL, Williams BA, Vallejo M, Kentor ML. Adverse outcomes associated with stimulator-based peripheral nerve blocks with versus without ultrasound visualization. Reg Anesth Pain Med. 2009; 34: 251-255.

5. Opperer M, Gerner P, Memtsoudis SG. Additives to local anesthetics for peripheral nerve blocks or local anesthesia: A review of the literature. Pain Manag. 2015; 5: 117-28.

6. Swain A, Nag DS, Sahu S, Samaddar DP. Adjuvants to local anesthetics: Current understanding and future trends. World J Clin Cases. 2017; 5: 307.

7. Suresh S, Ecoffey C, Bosenberg A.et al.The European society of regional anaesthesia and pain therapy/American society of regional anesthesia and pain medicine recommendations on local anesthetics and adjuvants dosage in pediatric regional anesthesia.Reg Anesth Pain Med. 2018; 43: 211-216.

8. Dillane D, Finucane BT. Local anesthetic systemic toxicity. Can J Anesth Can D’anesthésie. 2010; 57(4): 368-380.

9. Merella F, Canchi Murali N. General principles in regional anesthesia in children. BJA education vol 19. August 2019. DOI:https://doi. org/10.1016/j.bjar.2019.06.003.
10. Fettiplace M.R, Weinberg G. The mechanisms underlying lipid resuscitation therapy. Reg Anesth Pain Med. 2018; 43: 138-149.

11. Clinical Guidelines for the Recognition and Assessment of Acute Pain in Children. Royal College of Nursing Institute, 2009. Available at: www.rcn.org.uk/childrenspain guideline.

12. von Baeyer CL, Forsyth SJ, Stanford EA et al. Response biases in preschool children's ratings of pain in hypothetical situations. Eur J Pain 2009; 13: 209-213.

13. Buttner W, Fincke W. Analysis of behavioural and physiological parameters for the assessment of postoperative analgesic demand in newborns, infants and young children. Paediatr Anaesth 2000; 10: 303-318.

14. Gregorio G Di, Neal JM, Rosenquist RW, Weinberg GL. Clinical presentation of local anesthetic systemic toxicity: a review of published cases, 1979 to 2009. Reg Anesth Pain Med. 2010; 35: 181-187.

15. Weinberg GL. Treatment of local anesthetic systemic toxicity (LAST). Reg Anesth Pain Med. 2010; 35: 188-193.

16. Barson AJ,Chistwick ML, Doig CM. Fat embolism in infancy after intravenous fat infusions. Arch Dis Child. 1978; 53: 218-223.

17. Zausig YA, Graf BM, Zink W. Is it "lipid sink," hemodilution, or both? Critical Care Medicine. 2009; 37(10): p. 2863.

18. Walker BJ, Long J, Madhankumar S. et al. Complications in pediatric regional anesthesia: an analysis of more than 100,000 blocks from the Pediatric Regional Anaesthesia Network.Anesthesiology. 2018; 129: 721-732.

19. Berde CB: Toxicity of local anesthetics in infants and children. J Pediatr 1993; 122(Pt 2): S14-S20.

20. Tschopp C, Tramèr MR, Schneider A, Zaarour $\mathrm{M}$, Elia N. Benefit and harm of adding epinephrine to a local anesthetic for neuraxial and locoregional anesthesia: a meta-analysis of randomized controlled trials with trial sequential analyses. Anesth Analg 2018; 127: 228-239. doi: 10.1213/ ANE.0000000000003417.

21. Pietraszek P. Regional anaesthesia induced peripheral nerve injury. Anaesthesiol Intensive Ther 2018; 50: 367-377. doi: 10.5603/AIT. 2018.0049

22. Komatsu T, Takenami T, Nara Y, et al. Epinephrine administered with lidocaine solution does not worsen intrathecal lidocaine neurotoxicity in rats. Reg Anesth Pain Med 2013; 38: 140-144. doi: 10.1097/AAP. 0b013e318279499d.

23. Brummett CM, Williams BA. Additives to local anesthetics for peripheral nerve blockade. Int Anesthesiol Clin. 2011; 49: v104-116.

24. Myers RR, Heckman HM. Effects of local anesthesia on nerve blood flow: studies using lido- 
caine with and without epinephrine. Anesthesiology. 1989; 71: 757-762.

25. Kapral S, Krafft P, Eibenberger K, Fitzgerald R, Gosch M, Weinstabl C. Ultrasound-guided supraclavicular approach for regional anesthesia of the brachial plexus. Anesth Analg. 1994; 78: 507 Y513.

26. Neal JM. Effects of epinephrine in local anesthetics on the central and peripheral nervous systems: neurotoxicity and neural blood flow. Reg Anesth Pain Med. 2003; 28(2): 124-134.

27. Neal JM, Barrington MJ, Fettiplace MR, et al. The third American Society of Regional Anesthesia and Pain Medicine practice advisory on local anesthetic systemic toxicity: executive summary 2017. Reg Anesth Pain Med 2018; 43: 113-123. doi: 10.1097/AAP. 0000000000000720.16

28. Choi S, Rodseth R, McCartney CJ. Effects of dexamethasone as a local anaesthetic adjuvant for brachial plexus block: a systematic review and meta-analysis of randomized trials. Br J Anaesth. 2014; 112(3): 427-39.

29. Kirkham KR, Jacot-Guillarmod A, Albrecht E. Optimal dose of perineural dexamethasone to prolong analgesia after brachial plexus blockade: a systematic review and meta-analysis. Anesth Analg 2018; 126: 270e9.
30. Ma R, Wang $\mathrm{X}, \mathrm{Lu} \mathrm{C}$, et al. Dexamethasone attenuated bupivacaine-induced neuron injury in vitro through a threonine-serine protein kinase B-dependent mechanism. Neuroscience 2010; 5: 67: 329-342. doi: 10.1016/j.neuroscience.2009.12.049.

31. Polderman JAW, Farhang-Razi V, van Dieren S et al. Adverse side-effects of dexamethasone in surgical patients - an abridged Cochrane systematic review. Anaesthesia 2019.

32. Biradar PA, Kaimar P, Gopalakrishna K. Effect of dexamethasone added to lidocaine in supraclavicular brachial plexus block: A prospective, randomised, double-blind study. Indian J Anaesth. 2013; 57: 180-184.

33. Liu J, Richman KA, Grodofsky SR, Bhatt S, Huffman GR, Kelly JD 4th, Glaser DL, Elkassabany N. Is there a dose response of dexamethasone as adjuvant for supraclavicular brachial plexus nerve block? A prospective randomized double-blinded clinical study. J Clin Anesth. 2015; 27: 237-242.

34. Rahangdale R, Kendall MC, McCarthy RJ, Tureanu L, Doty R Jr, Weingart A, De Oliveira GS Jr. The effects of perineural versus intravenous dexamethasone on sciatic nerve blockade outcomes: a randomized, double-blind, placebo-controlled study. Anesth Analg. 2014; 118: 1113-1119. 


\title{
Резиме
}

АДРЕНАЛИНОТ И ДЕКСАМЕТАЗОНОТ КАКО АДЈУВАНСИ ПРИ ПЕРИФЕРНИ НЕРВНИ БЛОКОВИ НА ГОРНИТЕ ЕКСТРЕМИТЕТИ КАЈ ПЕДИЈАТРИСКИТЕ ПАЦИЕНТИ

\author{
Љубица Миќуновиќ Деребанова ${ }^{1}$, Андријан Карталов, ${ }^{1,2}$ Биљана Кузмановска ${ }^{1,2}$,

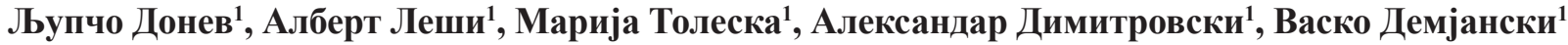 \\ 1 Универзитетска клиника за анестезија, реанимација и интензивно лекување - Скопје, РС \\ Македонија \\ ${ }^{2}$ Медицински факултет, Универзитет „Св. Кирил и Методиј“ - Скопје, РС Македонија
}

Вовед: Регионалната анестезија кај деца во последните години е широко прифатена. Зголемената заинтересираност за неа делумно се должи и на примената на ултрасонографијата, која дава сигурност и прецизност кај анестезиолошкиот тим. Адјувансите се користат со цел да се продолжи времетраењето на сензорниот и на моторниот блок, лимитирајќи ја кумулативната доза на локалните анестетици. Употребата на адјуванси при периферни нервни блокови во педијатриската популација сѐ уште е во фаза на истражување.

Цел: Целта на студијата е да се докаже ефектот на адреналинот и на дексаметазонот како адјуванси на локалните анестетици при периферни нервни блокови на горните екстремитети кај педијатриските пациенти.

Материјали и методи: Во студијата се опфатени 63 пациенти од 4-14-годишна возраст примени на Универзитетската клиника за детска хирургија за оперативен третман на скршеница на горен екстремитет во периодот јануари 2020 - март 2021 година. Пациентите се рандомизирани во три групи и сите пациенти од групите добиле интравенска аналгоседација (мидазолам $0,1 \mathrm{mg} / \mathrm{kg}$ i.v., фентанил $1 \mu \mathrm{g} / \mathrm{kg}$ i.v. и пропофол 5-10 mg/ $\mathrm{kg} / \mathrm{h}$ ) пред изведување на периферниот нервен блок. Кај пациентите во првата група (21 пациент) се аплицирал супраклавикуларен или интерскаленски блок со $2 \mathrm{ml}$ лидокаин $2 \%$ и бупивакаин $0,25 \%(\max 2 \mathrm{mg} / \mathrm{kg})$ со вкупен волумен од $0,5 \mathrm{ml} / \mathrm{kg}$. Во втората група пациенти (21) се аплицирале $25 \mu \mathrm{g}$ адреналин во $2 \mathrm{ml}$ на $2 \%$ раствор на лидокаин и $0,25 \%$ бупивакаин $(\max 2 \mathrm{mg} / \mathrm{kg}$ ) со вкупен волумен од $0,5 \mathrm{ml} / \mathrm{kg}$ и во третата група (21) $2 \%$ лидокаин $2 \mathrm{ml}$ и $0,25 \%$ бупивакаин ( $\max 2 \mathrm{mg} / \mathrm{kg}$ ) во комбинација со $2 \mathrm{mg}$ дексаметазон со вкупен волумен од $0,5 \mathrm{ml} / \mathrm{kg}$.

Резултати: Во студијата се покажа дека кај пациентите во првата група просечното времетраење на сензорниот блок изнесуваше 7 часа, додека времетраењето на моторниот блок изнесуваше 5 часа и 30 мин. Во втората група (адреналин) времетраењето и на сензорниот и на моторниот блок беше продолжено во просек околу 30 минути во однос на првата група. Во третата група (дексаметазон) времетраењето на сензорниот и моторниот блок беше сигнификантно подолго во споредба со првите две групи $(\mathrm{p}<0.0001)$.

Заклучок: Адреналинот и дексаметазонот го продолжуваат времетраењето на дејството на локалните анестетици при периферни нервни блокови на горните екстремитети кај педијатриските пациенти, а со тоа и ја намалуваат потребата од аналгетици во постоперативниот период.

Клучни зборови: адреналин, дексаметазон, адјуванси, периферни нервни блокови на plexus brachialis, педијатриски пациенти 